\title{
STUDY ON THE MECHANIZATION OF BEAN (Phaseolus vulgaris) CROP UNDER EGYPTIAN CONDITIONS
}

\author{
M.A. Hassan ${ }^{1}$ \\ Hanan M. El-Shal ${ }^{3}$ \\ M.K. Afify ${ }^{2}$ \\ Alaa A.A. Abd El-Atty ${ }^{4}$ \\ ABSTRACT
}

This study aimed to select the proper system of bean crop mechanization to achieve high yield, low grain losses with high field efficiency. The experiments were carried out using pneumatic planter and seed drill in planting operations in addition to the manual method, and tractor mounted mower was used in harvesting operation under different forward speeds and moisture contents compared to the manual method. Also, a Turkish threshing machine was used for threshing the crop at different drum speeds and seed moisture contents. From the obtained data it was concluded that; the pneumatic planter followed by tractor mounted mower and threshing by Turkish machine was considered the proper system for producing dry bean under Egyptian conditions, where as required minimum cost compared to the others. The seed moisture content of $14.86 \%$ and forward speed of $2.9 \mathrm{~km} / \mathrm{h}$ were the proper conditions for harvesting dry bean crop. The threshing drum speed of $10.47 \mathrm{~m} / \mathrm{s}$ and seed moisture content of $11.33 \%$ considered the proper values for threshing bean.

Keywords: Bean, planting, harvesting, threshing, drum speed

\section{INTRODUCTION}

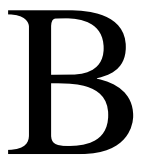

ean is considered one of the important legume crops all over the world. it is currently used in human feeding more over, bean residues are used as a filling material for animal feed. The total planted area in Egypt devoted for dry seeds at 2010 was 47000 feddan with production of about $53000 \mathrm{Mg}$ with (an average yield of 1.13 $\mathrm{Mg} /$ feddan).

\footnotetext{
${ }^{1}$ Professor Emeritus, Agric. Eng. Dept., Fac. of Agric., Zagazig Univ.,Egypt ${ }^{2}$ Professor,Agric. Eng. Dept., Fac. of Agric., Zagazig Univ., Egypt ${ }^{3}$ Lecturer, Agric. Eng. Dept., Fac. of Agric., Zagazig Univ., Egypt. ${ }^{4}$ Demonstrator, Agric. Eng. Dept., Fac.of Agric., Zagazig Univ., Egypt.
} 
Also the production was 63000 feddan for green pods with total production of about $271000 \mathrm{Mg}$ (an average yield of $4.3 \mathrm{Mg} /$ feddan) according to Agricultural Economics Bulletin (2010).The dry bean procedures face many problems such as labor shortage as well as high wages in new lands. Sabreen et al., (2002) used pneumatic and mechanical planter for planting soybean at four forward speeds (3.6, 4.7, 5.6 and $6.9 \mathrm{~km} / \mathrm{h}$ ) at three levels of soil moisture contents $(34.22,28.60$ and $22.30 \%$ ). The field experiments showed that the proper planting method producing the highest germination ratio, uniformity of seed distribution, adequate depth planting and the highest productivity was pneumatic planter. They stated that the optimum soil moisture content and forward speed that gave the highest germination ratio, uniformity of seed distribution and total yield were $34.60 \%$ and $3.6 \mathrm{~km} / \mathrm{h}$, respectively. Neagu et al., (2002) determined that the degree of kidney bean [Phaseolus vulgaris] plant dislocation and grain losses at the running speed of $5.3 \mathrm{~km} / \mathrm{h}$ using three equipments with different active parts: special unilateral action knives, toothed swivel disc and double knife mower. The best results were recorded in the case of using the special unilateral action knives while the least was observed on the toothed swivel disc. Gomaa (2003) compared the performance of two types of planters (pneumatic and mechanical) in cowpea planting. The best seed germination, seed scattering, planting depth and total yield were obtained under planting forward speed of $3.16 \mathrm{Km} / \mathrm{h}$. he found also the best results of planting uniformity and total yield were obtained using pneumatic planter compared to mechanical planter. Herbek and Bitzer (2004) reported that the acceptable range for harvesting soybeans was between 11 and $20 \%$ of moisture content. A good rule is to start as soon as the moisture content reaches 14 to $16 \%$ and continue until the field is harvested. They suggested harvesting promptly when moisture content reaches $13 \%$ and to finish before moisture content drops to $11 \%$. Below that level, shatter losses and seed damage losses increase substantially. On the other hand, the cylinder speeds ranging from 400 to $800 \mathrm{rpm}$ were normally adequate and that higher cylinder speeds of 700 to $800 \mathrm{rpm}$ caused greater seed damages than slower speeds, and use a cylinder speed lower than $500 \mathrm{rpm}$ recorded seed damage .Yehia et al., (2005) reported 
that the highest grain emergence percentage of cowpea was recorded in the case of using pneumatic planter comparing with manual planting, seed drill and mechanical planter in flat and furrow soil. They added that the maximum grain emergence of $99.1 \%$ was obtained by using pneumatic planter in furrow while the minimum of $62.44 \%$ was obtained by using manual planting in flat soil. They reported also, the highest seed productivity of $(1313 \mathrm{~kg} / \mathrm{fed})$ was obtained by using pneumatic planter in furrow soil in comparison to the others. Morad et al. (2007) showed that the average values of yield of cowpea production were 408.7, 567.3 and 472.5 $\mathrm{kg} /$ fed under manual planting, pneumatic planter and seed drill, respectively. As mentioned before, dry bean production still depends mainly on manual methods especially in small holdings with consuming more time and cost. For this reason, the objectives of this study concerned as follow:

1. Selecting the proper system for planting and harvesting bean crop to reach to high yield, low grain losses with high field efficiency.

2. Selecting the optimum seed moisture content and operating speed to minimize the harvesting and threshing losses.

3. Reducing the total cost and energy requirement through selecting the proper system for bean mechanization.

\section{MATERIALS AND METHODS}

The main experiments were carried out during the agricultural season of 2009/2010 at Diarb Negm, Sharkia Governorate,Egypt to investigate some different mechanization systems for producing Bean (Giza 6 variety) under Egyptian conditions. The experimental area was about 1.5 fed divided into 27 equal plots with dimensions of $(3 \times 78 \mathrm{~m})$ for each. The mechanical analysis of the experimental soil was classified as clay soil as indicated in Table (1).

\section{A-Materials:}

The following equipment were used in the research:

- Roman tractor "Universal 650-M" with power of $55.93 \mathrm{~kW}$.

- Nasr Tractor " M34/T diesel water cooled" with power of $44.1 \mathrm{~kW}$.

- Four rows pneumatic planter, model GAMMA 90 with working width of $240 \mathrm{~cm}$.

- 21 rows seed drill, model COLORADO with working width of $240 \mathrm{~cm}$.

- Tractor mounted mower model B.M.1102 with cutting width of $150 \mathrm{~cm}$. 
- Self-propelled harvester model 4G-120A with cutting width of $120 \mathrm{~cm}$ and $8.82 \mathrm{~kW}$ engine power.

- Turkish threshing machine consists of two components; threshing and winnowing units. The threshing drum of $120 \mathrm{~cm}$ length, $73 \mathrm{~cm}$ diameter and number of fingers is 40. The winnowing unit having a fan, vibrating screen and air elevator.

Table(1): Soil mechanical analysis

\begin{tabular}{cccc}
\hline Clay \% & Silt \% & Sand \% & Textural class \\
\hline 52.9 & 24.55 & 22.55 & clay \\
\hline
\end{tabular}

B-Methods :

\section{- Planting operation}

The rows spacing and hills in the same row were almost adjusted to be $60 \mathrm{~cm}$ and $15 \mathrm{~cm}$ in both manual and mechanical methods respectively. The manual planting requires about $45 \mathrm{~kg} / \mathrm{fed}$ of seeds and the mechanical planting (planter and seed drill) requires about 15 and $26 \mathrm{~kg} / \mathrm{fed}$ respectively. The average number of seeds was 3-5 seed per hill under manual planting. Meanwhile, this was only done in the mechanical planting. Plots in different planting operations were thinned to one plant per hill after three weeks from planting. The planting depth was adjusted to be $4 \mathrm{~cm}$ at average forward speed of $3.75 \mathrm{~km} / \mathrm{h}$. Fertilizing, irrigation and weed control were the same in all treatments according to the technical recommendations.

\section{- Harvesting operation}

The harvesting operation was carried out through three different levels of seed moisture contents of 10.87, 14.86 and $20.43 \%(\mathrm{db})$ at different operating speeds of $2.9,3.8$ and $5.1 \mathrm{~km} / \mathrm{h}$.

\section{- Threshing operation}

The threshing operation was conducted on plants which obtained from the proper planting and harvesting treatments under three different drum speeds of 400, 500 and $600 \mathrm{rpm}$ [8.37, 10.47 and $12.56 \mathrm{~m} / \mathrm{s}$ ] at four moisture contents of $[8.61,11.33$ and $17.82 \%(\mathrm{db})]$ at a constant feed rate of $185 \mathrm{~kg} / \mathrm{h}$.

\section{-Treatments}

Nine treatments, namely A, B, C, D, E, F, G, H and I were carried out and replicated three times in a completely randomized block design. The 
preliminary experiment including treatments of $\mathrm{C}, \mathrm{F}$ and I that ignored because this experiment was carried out by self-propelled harvester and found that the harvesting losses was more than $50 \%$ so this method not used during the basic experiment.

A.: Manual planting + manual harvesting + threshing machine.

B.: Manual planting + Rear-tractor mounted mower + threshing machine.

D.: Pneumatic planter + manual harvesting + threshing machine.

E.: Pneumatic planter + Rear-tractor mounted mower + threshing machine.

G. : Seed drill + manual harvesting + threshing machine.

H. : Seed drill + Rear-tractor mounted mower + threshing machine.

\section{-Measurements:}

\section{-Plant measurements}

Germination ratio: A sample of (1000 seed) was germinated and replicated three times before and after planting to investigate seed germination.

Coefficient of variation: The coefficient of variation was measured using the following method. Deviation in row from recommended distance $(\%)$ that considered indicator to distribution uniformity. The deviation of hills on row from average distance $(C V)$ was estimated according to the following equation:

$$
C \cdot V=\frac{\sigma_{n-1}}{\bar{x}} \quad, \quad \sigma_{n-1}=\sqrt{\frac{\sum(x-\bar{x})^{2}}{n-1}}
$$

\section{Where:}

$\sigma_{n-1}:$ Standard deviation.

$\boldsymbol{x} \quad$ : Distance between hills on row.

$\bar{x} \quad$ : The recommended distance.

$n \quad$ : number of readings.

Crop yield: Random samples of plant with $1 \mathrm{~m}^{2}$ of area for each one were taken from different places in each treatment and seeds mass of plants was measured then, average weight seeds of plants $/ \mathrm{m}^{2}$ were calculated from next equation:

$$
\text { Average weight seeds of plants }=\frac{\text { weight of seeds in all samples }}{\text { Numberof samples }}
$$




\section{-Machine measurements:}

Theoretical Field capacity (TEC); It was determined by the following relationship:

$$
T E C=\frac{S x W}{4200} \quad,(\text { fed } / h)
$$

\section{Where:}

$S=$ Travel speed, $(\mathrm{m} / \mathrm{h})$.

$W=$ Rated width, (m).

The actual field capacity (EFC):It was calculated from the following formula:

$$
E E C=\frac{60}{T u+T i} \quad,(f e d / h)
$$

\section{Where:}

$T u=$ The utilized time per feddan in minutes.

$T i=$ The summation of lost time per feddan in minutes.

Field efficiency $\left(\eta_{f}\right)$ :It was calculated by using the following formula:

$$
\eta_{f}=\frac{E F C}{T F C} x 100
$$

\section{Where:}

$E F C=$ The effective field capacity of the machine, $(\mathrm{fed} / \mathrm{h})$.

$T F C=$ Theoretical field capacity of the machine, $(\mathrm{fed} / \mathrm{h})$.

\section{-Harvesting and threshing losses}

Harvesting losses percentage: It was measured as follows:

$$
\text { Harvesting losses, } \%=\frac{\text { Harvesting losses }(\mathrm{kg} / \mathrm{fed})}{\text { Total yield }(\mathrm{kg} / \mathrm{fed})} \times 100
$$

Threshing losses: the cracking and damaged seeds was estimated by taking sample of $1 \mathrm{~kg}$ of seeds that collected from the threshed seeds to determine the seed damage cracked percent, and the cleaning efficiency was considered.

\section{Threshing efficiency $\left(\eta_{t h}\right)$ :}

It can be calculated by using the following equation:

$$
\eta_{t h}=\frac{W-W_{1}}{W} \times 100
$$




\section{Where:}

$W=$ The total weight of the seeds (gm).

$\mathrm{W}_{1}=$ Mass of un-threshed from the seeds (gm).

\section{Cleaning efficiency $\left(\eta_{c l}\right)$ :}

It can be determined using the following equation:

$$
\eta_{c l}=\frac{W_{1}}{W_{o}} x 100
$$

\section{Where:}

$W_{l}=$ Weight of seeds from the main output opening after cleaning (gm).

$W_{O}=$ Weight of the seeds small chaff from the main output opening (gm).

\section{Fuel consumption $(F c)$ :}

It was determined by measuring the volume of fuel required to refill the tank after operation time per each treatment, using a graduated glass cylinder $1000 \mathrm{~cm}^{3}$. It was calculated using the following equation:

\section{Where:}

$$
F C=\frac{V_{f}}{T} \times 3.6 \quad,(L / h)
$$

$V_{f}$ : Volume of fuel consumption, $\left(\mathrm{cm}^{3}\right)$.

$T$ : Time of operations, (s)

\section{Engine power:}

The required power was calculated using the following formula (Barger, et al.,1963):

\section{Where:}

$$
P=W f \times c . v . \times \eta_{t h} \times \frac{427}{75} \times \frac{1}{1.36},(k W)
$$

$W f=$ Rate of fuel consumption, $(\mathrm{kg} / \mathrm{s})$

c.v. = Calorific value of fuel in $\mathrm{Kcal} / \mathrm{kg}$ of fuel .

$427=$ Thermo-mechanical equivalent, $(\mathrm{Kg} \cdot \mathrm{m} / \mathrm{Kcal})$.

$\eta_{t h}=$ Thermal efficiency of the engine.(\%).

Specific Energy Requirement: It can be calculated by the following equation:

Specific energy requirements $=\frac{\text { Power required }(k w)}{\text { Effective field capacity }(\text { fed } / h)},(k W . h / f e d)$ 


\section{-Costs}

The cost of mechanized process was based on the initial cost of machine, interest on capital, cost of fuel and oil consumed, cost of maintenance, and wage of operator according to the following formula (Awady, 1978):

Where:

$$
C=\frac{p}{h}\left(\frac{1}{a}+\frac{i}{2}+t+r\right)+(0.9 W \times s \times f)+\frac{m}{144}
$$

$C=$ Hourly cost, L.E/h.

$P=$ price of machine, L.E

$h=$ Yearly working hours, h/year.

$a=$ Life expectancy of the machine, year.

$i=$ Annual interest rate, $\%$.

$t=$ Annual taxes, over heads rate, $\%$.

$r=$ Annual repairs and maintenance rate, $\%$.

$f=$ fuel price, L.E.

$0.9=\mathrm{A}$ factor including reasonable estimation of the oil consumption in addition to fuel.

$W=$ Engine power, $\mathrm{hp}$.

$S=$ Specific fuel consumption, $\mathrm{L} / \mathrm{hp} . \mathrm{h}$.

$m=$ Monthly average wage, L.E.

$144=$ Reasonable estimation of monthly working hours.

Hence, the creterion cost can be determined as following:

$$
\text { The creterion costs, } \mathrm{L} . \mathrm{E} / \mathrm{Mg}=\frac{\text { Machine cost },(\mathrm{L} . \mathrm{E} / \mathrm{h})}{\text { Machine productivity },(\mathrm{Mg} / \mathrm{h})}
$$

\section{RESULTS AND DISCUSSION}

\section{1-Effect of different planting methods on some plant characteristics and germination ratio:}

The obtained results in Table (2) showed that the highest germination ratio of $96 \%$ was recorded under the manual method, while it decreased to 94 and $91.5 \%$ under pneumatic planter and seed drill respectively. This is may be due to the effect of the friction and compact forces between seeds and feeding system that may be caused a damage on the seeds and that leads to reduce the germination ratio in case of using seed drill and pneumatic planter. 


\section{Coefficient of variation}

The obtained results in Table (2) show that the values of distribution uniformity were $11.32,17.01$ and $23.9 \%$ for the pneumatic planter, seed drill and manual planting, respectively. That is because the distance between seeds in the same row can be controlled in the case of using pneumatic planter better than the others.

\section{-Crop yield}

It is cleared from Table (2) that the obtained values of yield were $1206.24,1440.81$, and $1337.99 \mathrm{~kg} / \mathrm{fed}$ under manual planting, pneumatic planter, and seed drill, respectively. The high total yield with the use of pneumatic planter was attributed to the high number and weight of seed per plant. So, the mechanical planting using pneumatic planter is the advisable method for planting bean because of its high resulting yield.

\section{2-Effect of harvesting method on field capacity and efficiency:}

Fig.(3) shows that the effect of forward speed of the harvesting machine on both field capacity and efficiency for manual and mechanical methods of harvesting. The obtained results for mechanical methods showed a drop in field efficiency with a consequent sharp rise in the field capacity as the forward speed increased. The increase of forward speed from 2.9 to $5.1 \mathrm{Km} / \mathrm{h}$ was followed with an increase in field capacity values from 0.870 to $1.210 \mathrm{fed} / \mathrm{h}$ for rear-mounted mower and a decrease in field efficiency values from 84.04 to $66.42 \%$ under the same previous condition was occurred. The major reason for the reduction in field efficiency is due to the less consumption of the theoretical operation time in comparison with the other items of time losses. The average forward speed of $2.9 \mathrm{Km} / \mathrm{h}$ is recommended because increasing it more than 2.9 will decrease the field efficiency, while decreasing it less than $2.9 \mathrm{Km} / \mathrm{h}$ will decrease the field capacity and increase the field efficiency.

Table (2):Effect of planting methods on some plant characteristics

\begin{tabular}{lccc}
\hline Planting methods & $\begin{array}{c}\text { C.V } \\
(\boldsymbol{\%})\end{array}$ & $\begin{array}{c}\text { Germination ratio } \\
(\mathbf{\%})\end{array}$ & $\begin{array}{c}\text { Crop yield } \\
(\mathbf{~ k g} / \mathbf{f e d})\end{array}$ \\
\hline Manual planting & 23.9 & 96 & 1206.24 \\
Pneumatic planter & 11.32 & 94 & 1440.81 \\
seed drill & 17.01 & 91.5 & 1337.99 \\
\hline
\end{tabular}




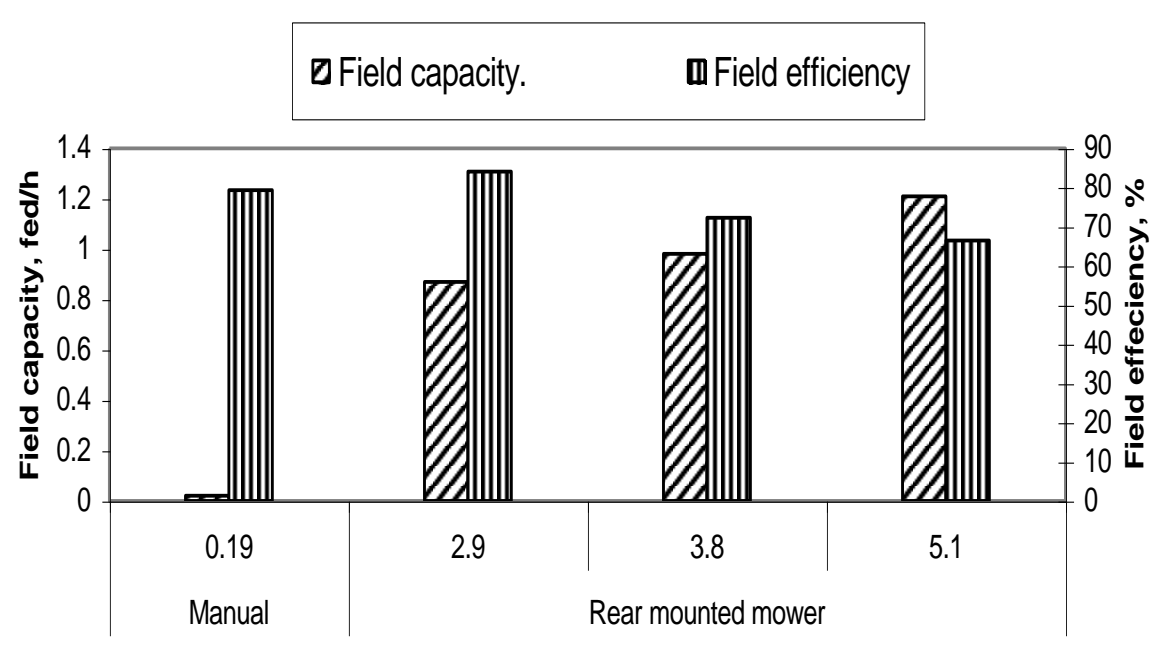

Forward speed, $\mathrm{km} / \mathrm{h}$

Fig.(3):The effect of forward speed on field capacity and field efficiency at moisture content of $14.86 \%$.

\section{3-Effect of different operating parameters on harvesting losses:}

Fig.(4) showed that the manual harvesting at forward speed of 0.19 $\mathrm{Km} / \mathrm{h}$., and seed moisture content of $14.86 \%$ gave seed losses of 0.76 , 1.00 , and $0.65 \%$ under the manual planting, pneumatic planter, and seed drill, respectively. For the mechanical harvesting by using tractormounted mower, it was found that increasing forward speed from 2.9 to $5.1 \mathrm{Km} / \mathrm{h}$., moisture content of $14.86 \%$ increased seed losses from 6.44 to $10.45 \%$, from 5.45 to $8.36 \%$, and from 6.18 to $9.26 \%$ under manual planting, pneumatic planter and seed drill, respectively. The increase of grain losses by increasing forward speed may be attributed to the excessive load of plants on the cutter bar and in the same time, increasing the impact times of cutter bar with plants per unit of time. On the other hand, it noticed that the lowest harvesting losses were occurred with the manual harvesting. Relating to the effect of seed moisture content on harvesting losses, Fig.(5) Show that, the increase of seed moisture content caused a clear decrease in harvesting losses. 


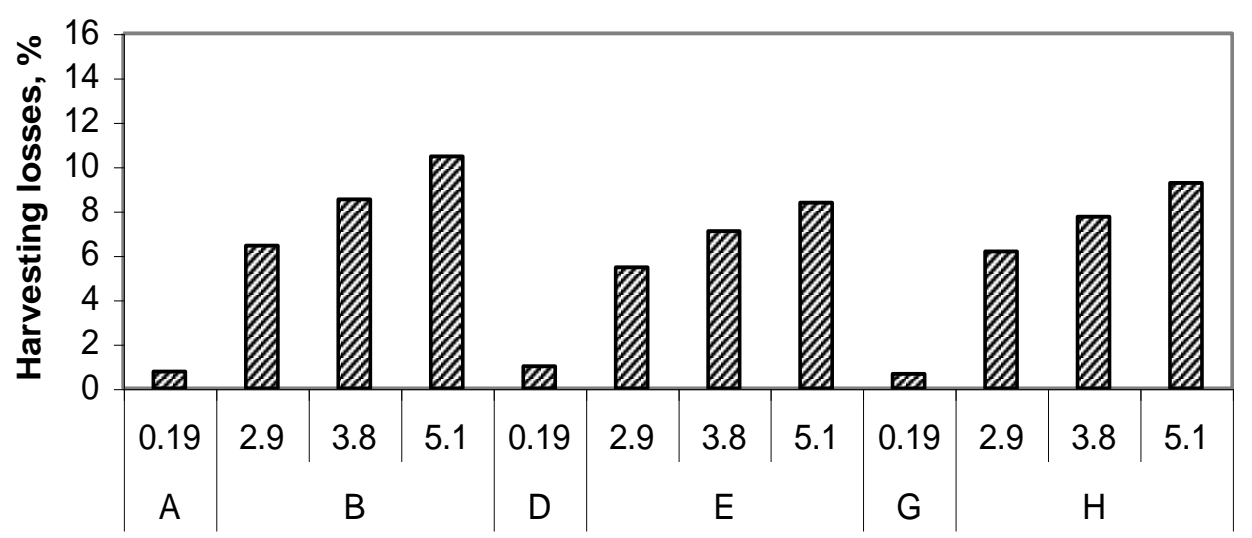

Forward speed, km/h

Fig.(4):Effect of harvesting methods and forward speeds on harvesting losses under different planting methods at moisture content of $14.86 \%$.

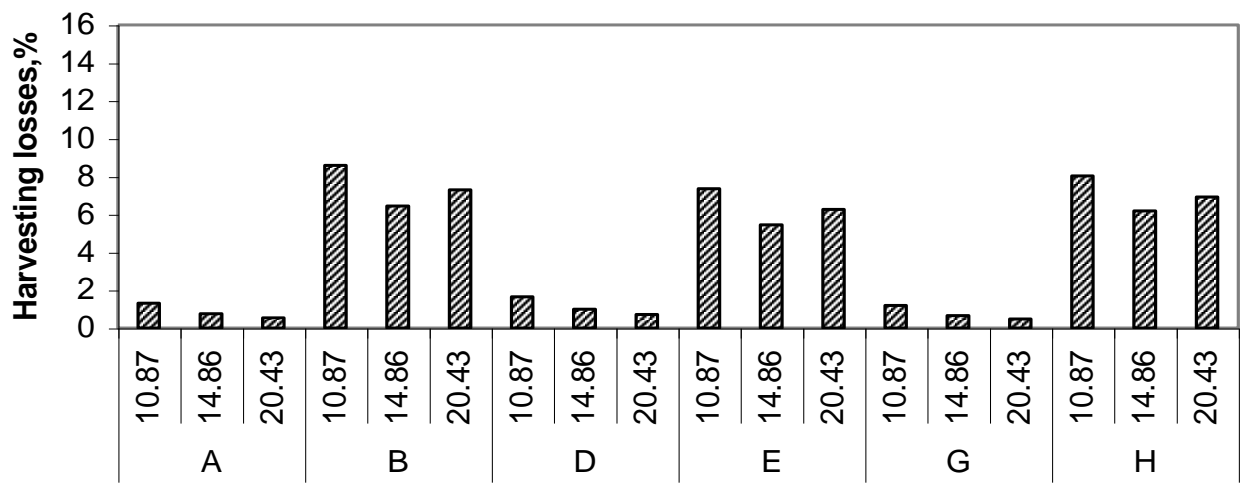

Moisture content, $\%$

Fig.(5):Effect of harvesting methods and moisture content on harvesting losses under different planting methods at average forward speed of $2.9 \mathrm{~km} / \mathrm{h}$.

For the manual harvesting, increasing moisture content from 10.87 to $20.43 \%$, at forward speed of $0.19 \mathrm{~km} / \mathrm{h}$ decreased the harvesting losses from 1.31 to $0.53 \%$, from 1.64 to $0.71 \%$, and from 1.19 to $0.47 \%$ under manual planting, pneumatic planter, and seed drill, respectively.

Regarding to the mechanical harvesting using rear mounted mower, the increase of moisture content from 10.87 to $14.86 \%$ at forward speed of 2.9 $\mathrm{Km} / \mathrm{h}$, decreased harvesting losses from 8.59 to $6.44 \%$, from 7.36 to $5.45 \%$, 
and from 8.03 to $6.18 \%$ under manual planting, pneumatic planter, and seed drill, respectively. Also, increasing the moisture content from 14.86 to 20.43 $\%$ at the same speed increased harvesting losses from 6.44 to $7.3 \%$, from 5.45 to $6.26 \%$ and from 6.18 to $6.91 \%$ under the same previous treatments. So, the moisture content of $14.86 \%$ and the average of forward speed of $2.9 \mathrm{~km} / \mathrm{h}$ will be recommended for harvesting the bean crop by using the tractor mounted mower.

\section{4-Effect of different operating parameters on threshing losses and threshing efficiency:}

\section{- Un-threshed pods}

Fig.(6) show the relationship between un-threshed pods and different drum speeds at different seed moisture contents. The obtained results revealed that both drum speed and seed moisture content affected deeply on the percentage of un-threshed pods. The highest value of un-threshed pods of $6.25 \%$, was observed under the high level of seed moisture content of 17.82 $\%$, and the low drum speed of $8.37 \mathrm{~m} / \mathrm{s}$, while the lowest value of $0.64 \%$, was recorded under the low seed moisture content of $8.61 \%$ and the high drum speed of $12.56 \mathrm{~m} / \mathrm{s}$.

\section{-Mechanical seed damage}

Fig. (7) Show the relationship between seed damage and different drum speeds at different seed moisture contents. It is noticed that minimum values of mechanical seed damage were recorded at low drum speeds of $8.37 \mathrm{~m} / \mathrm{sec}$ (400r.p.m.), and high seed moisture content of $17.82 \%$.

\section{-Total threshing losses}

Fig. (8) show the relationship between total losses (including un-threshed pods and damaged seeds) and different drum speeds at different seed moisture contents. It is noticed that the minimum threshing losses of $7.06 \%$ can be achieved at a drum speed of $10.47 \mathrm{~m} / \mathrm{s}$ (500 r.p.m.) and seed moisture content of $11.33 \%$.

\section{-Effect of different operating parameters on threshing efficiency:}

Threshing efficiency was affected by many variables such as drum speed and seed moisture content. Fig.(9) indicated that the threshing efficiency increased from 93.75 to $96.42 \%, 96.83$ to $98.38 \%$, and 98.33 to $99.36 \%$ by increasing drum speed from 8.37 to $12.56 \mathrm{~m} / \mathrm{s}$, at average seed 
moisture content of $17.82,11.33$ and $8.61 \%$, respectively. On the other hand, threshing efficiency decreased by increasing seed moisture content, where the seeds cannot be separated easily as results, the percentage of un-threshed grains increased.

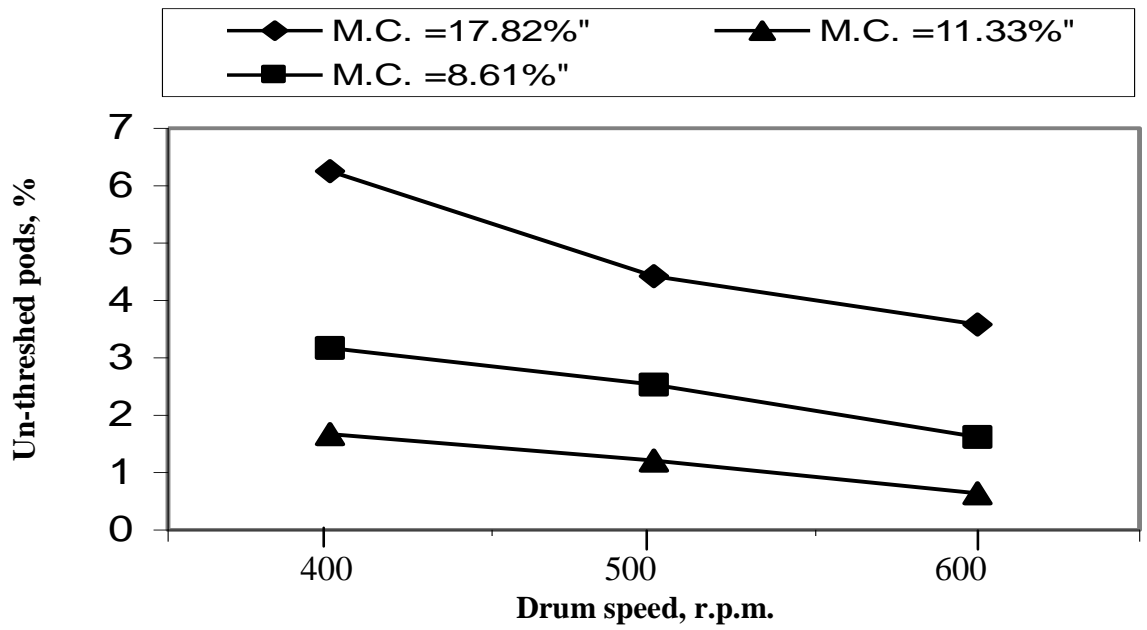

Fig.(6):Effect of drum speed and different seed moisture contents on the un-threshed pods.

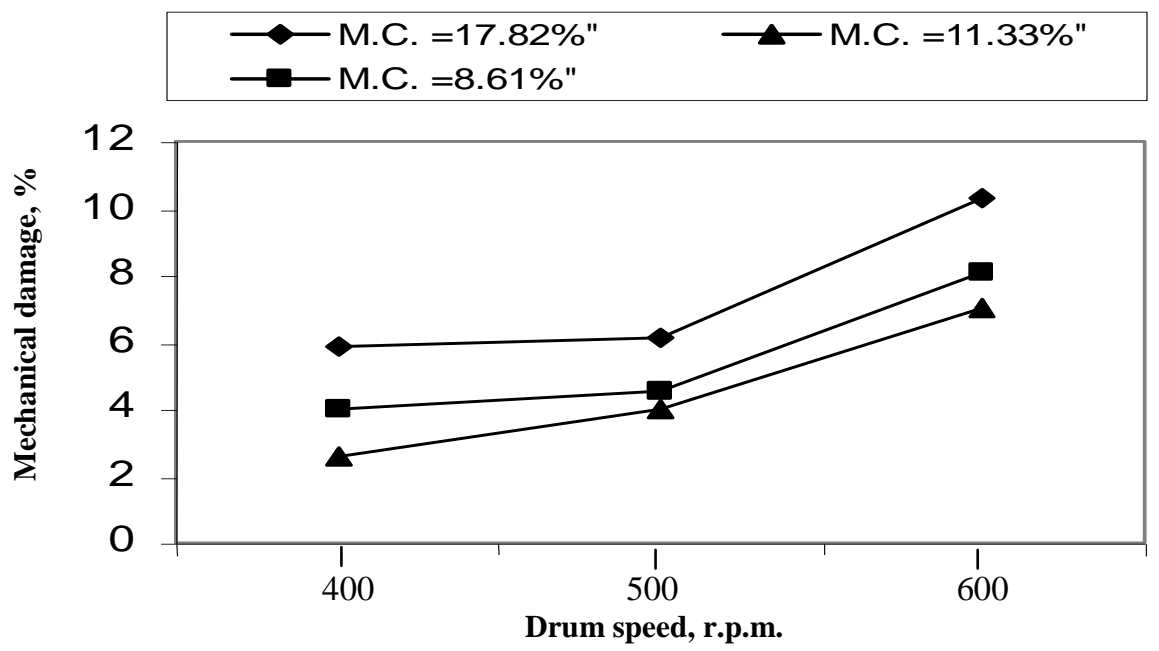

Fig. (7): Effect of drum speed and different seed moisture contents on the mechanical seed damage. 


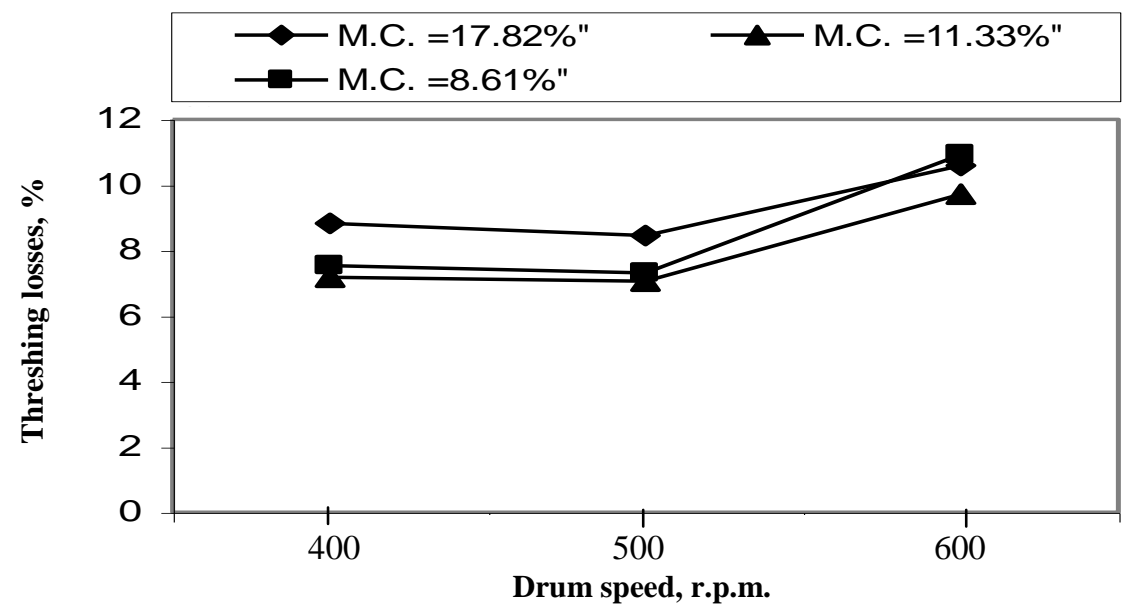

Fig. (8):Effect of drum speed on threshing losses using different seed moisture contents.

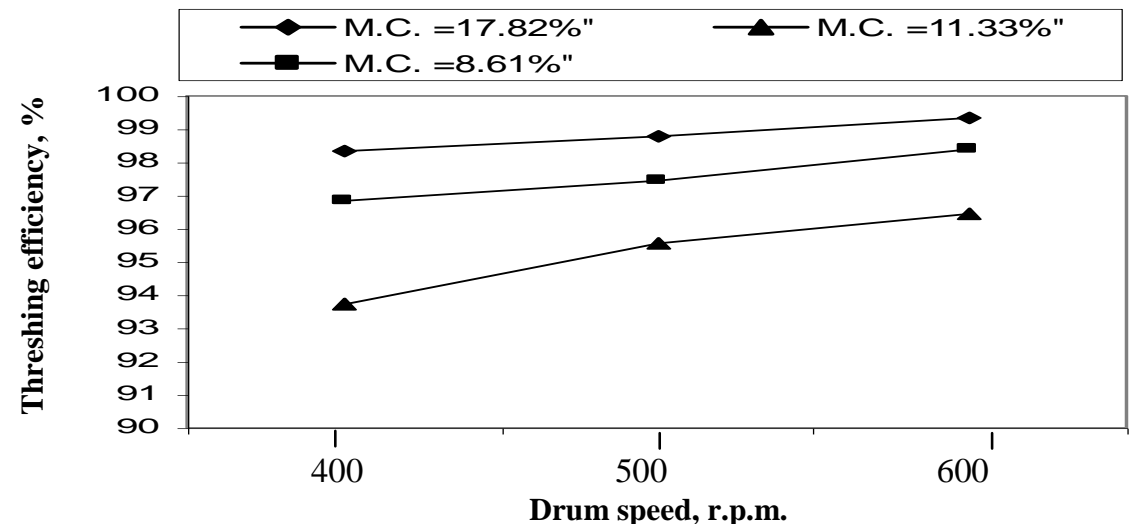

Fig. (9): Effect of drum speed on threshing efficiency using different seed moisture contents.

\section{5-Effect of different operating parameters on cleaning efficiency:}

Fig.(10) show the relation between cleaning efficiency and different drum speeds at different seeds moisture contents. The cleaning efficiency increased from 90.68 to $94.33,93.45$ to 96.2 , and 95.36 to $98.39 \%$, at seed moisture content of $17.82,11.33$, and $8.61 \%$, respectively by increasing drum speed from 8.37 to $12.56 \mathrm{~m} / \mathrm{s}$.From the previous data of the threshing process, it can be concluded that, the range of moisture content from 8.61 to $11.33 \%$ and the drum speed of $10.47 \mathrm{~m} / \mathrm{s}$, are considered the optimum operating conditions to minimize the losses percentage. 


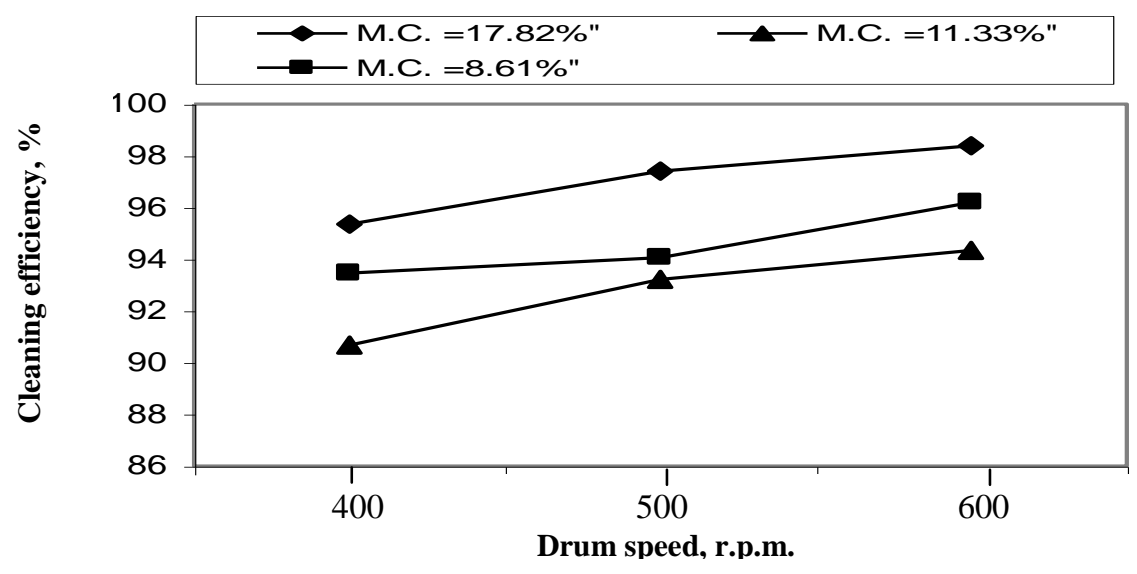

Fig. (10): Effect of drum speed on cleaning efficiency under different seed moisture contents

\section{6-Energy requirement for different bean mechanization systems:}

Fig.(11) show that the total energy requirement to produce one mega gram of dry bean for the used treatments can be arranged in descending order as follows: H, B, E, G, D, and A. It is clear that the treatment $(\mathrm{H})$ (mechanical planting by seed drill + mechanical harvesting by tractor mounted-mower + threshing by threshing machine) required the highest value of energy (47.90 $\mathrm{kW} . \mathrm{h} / \mathrm{Mg}$ ), while treatment (A) (manual planting + manual harvesting + threshing by threshing machine) required the lowest value of energy (22.90 $\mathrm{kW} \cdot \mathrm{h} / \mathrm{Mg}$ ).

\section{6-Cost analysis for bean production}

The cost of the field machinery is dependent on many factors due to the machine conditions and the mechanization system.Fig.(12) represents the cost per unit of production for the different treatments. The cost of production per ton of yield can be arranged in descending order of the treatments as follows: A (305.38 L.E. /Mg), G (206.25 L.E. /Mg), D (188.01 L.E/ton), B (171.65 L.E/Mg), H (80.55 L.E/Mg), and E (70.64 L.E./Mg), respectively. Treatments B, D, E, G, and $\mathrm{H}$ reduced the cost of operation by $43.79,38.43,76.86,32.46$, and $73.623 \%$, respectively, comparing to the conventional treatment A (305.38 L.E. $/ \mathrm{Mg}$ ). From this results, it is evident that treatment $\mathrm{E}$ (mechanical planting by pneumatic planter + mechanical harvesting by tractor mounted mower + mechanical threshing by threshing machine) recorded the lowest value of cost per unit production (70.64 L.E./Mg). 


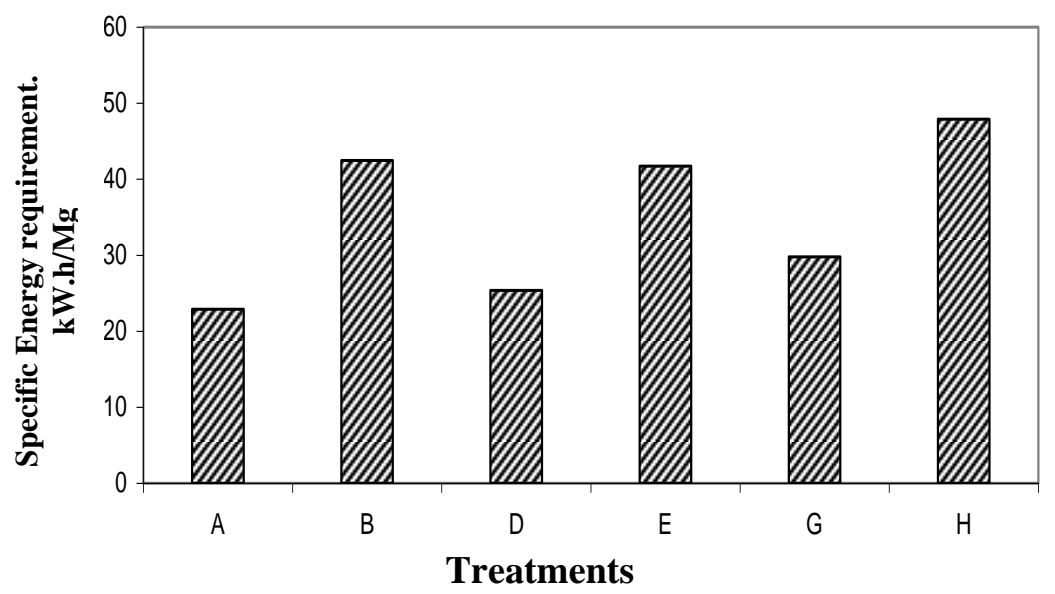

Fig.(11):Energy requirement for produce $1 \mathrm{Mg}$ of bean under the different treatments.

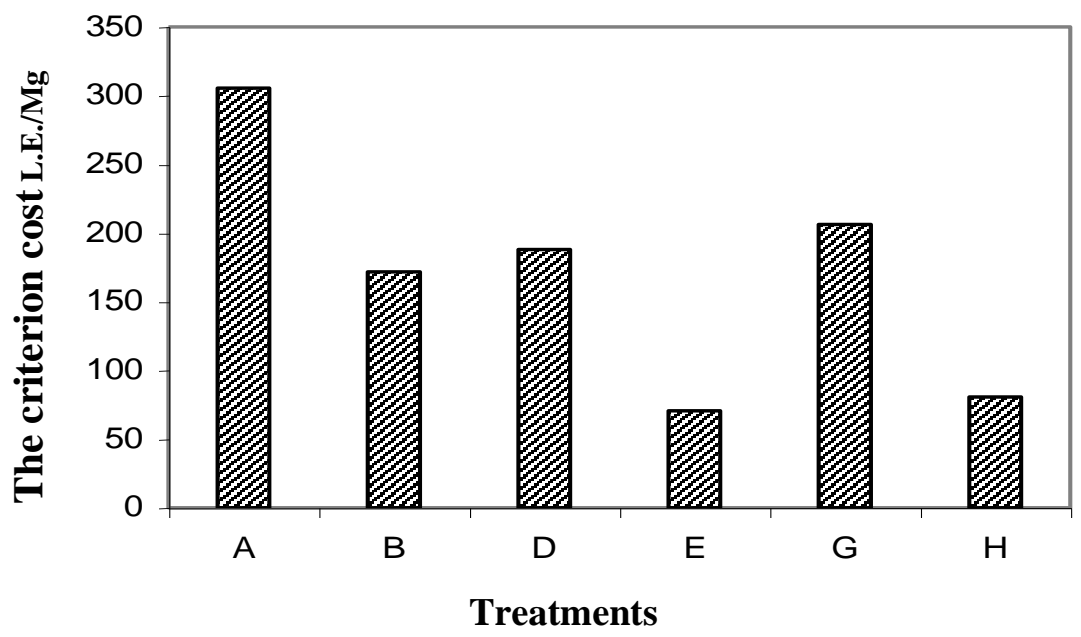

Fig.(12): The criterion cost to produce $1 \mathrm{Mg}$ of bean under the different treatments.

\section{CONCLUSION}

The obtained results showed that:

1- Treatment(E) that including the mechanical planting by Pneumatic planter + Rear-tractor mounted mower + mechanical threshing by threshing machine is recommended for production dry bean crop under Egyptian conditions as it requires minimum cost (70.64 L.E./Mg) and a high percent of return (profit $76.86 \%$ ) comparing with the other treatments. 
2- Seed moisture content of $14.86 \%$ and forward speed of $2.9 \mathrm{~km} / \mathrm{h}$ are recommended for harvesting the dry bean crop to minimize seed losses.

3- Drum speed of $10.47 \mathrm{~m} / \mathrm{s}$ (500 r.p.m.) and seed moisture content of 11.33 $\%$ are recommended for threshing dry bean crop as it recorded both the minimum losses and consumed energy of $7.06 \%$ and 23.13 kW.h./fed respectively.

\section{REFERENCES}

Agricultural economics bulletin.2010. Ministry of Agriculture, Cairo, Egypt.

Awady, M.N. 1978. Engineering of tractors and Agricultural machinery, (in Arabic), Textbook-Col. Agric., Ain Shams univ.,: pp:289.

Barger, E.L.;J.B. Lejdohl; W.M. Carleton and E.G. Mokibben .1963. Tractor and their power units. $2^{\text {nd }}$ ed., Wiley Sons. Inc., New York. U.S.A.

Gomaa, S.M. 2003.Performance evaluation of pneumatic and mechanical planters for cowpea planting. Misr J. Ag. Eng., 20 (4): 965 - 979.

Herbek, J.H. and M.J. Bitzer .2004. Harvesting, drying, storage, and marketing. Lexington, Ky: cooperative Extension Service Bulletin AGR, 132.

Morad, M.M., A.S. El-Kot, M.M. Ali and H.M. Salem.2007.Study on the mechanization of cowpea crop production under Egyptian conditions. Misr. J. Ag., Eng., 24 (3): 450-468.

Neagu, T.; P. Cojocariu; V. Valcu and P. Pilat.2002.Investigations on the mechanical dislocation of kidney bean. Cercetari Agronomic in Moldova, 35(1/2): 9-12

Sabreen, K.A., S.M. Sharaf and G.H. El-Sayed.2002. Soybean response to mechanical planting methods in clay-loam soil. Misr J. Ag. Eng., 19(2): 327-338.

Yehia, I.; S.E. Bader and A. Lotfy.2005. Effect of some planting systems on cowpea crop productivity. The 13th conference of the Misr Society of Agr., Eng., 14-15 December, : 670-678. 


\section{الملخص العربي}

\section{دراســة عن ميكنـة محصـول الفاصـوليـا تحث الظروف المصريـة}

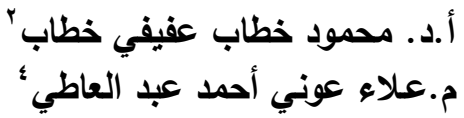

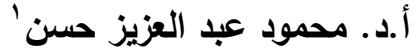

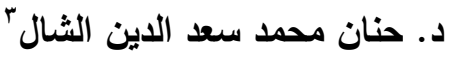

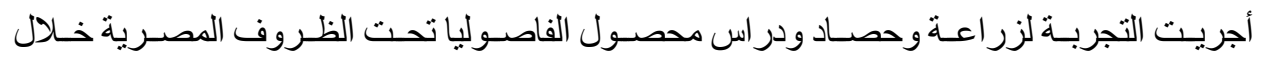

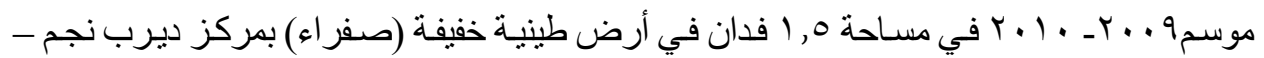
محافظة الثرقية. كانت أهداف الدر اسـة هي اختيـار أنسب طريقة لزر اعـة وحصـاد ودر اس محصول

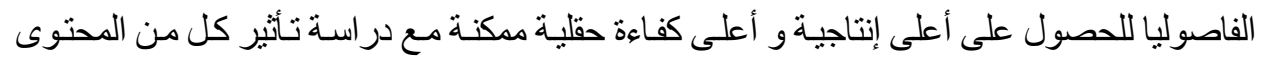
الرطوبي للحبوب و السرعات الامامية المختلفة على الفو اقد الحقليـة عند الحصـاد و كذللك دراسـة تأثير كل من المحتوى الرطوبي للحبوب و السر عات المختلفة للدرفيل على الفو اقد الحقلية عند الدر اس مـع العمل على خفض كل من التكـاليف والطاقة المستخدمة وذلك من خـلال إختيار النظام الامثل لميكنة محصسول الفاصسولياوقد أجريت التجربـة بـإستخدام المعاملات الآتيـة: (A) زر اعة يدوي + حصساد يدوي + در اس بآلة الدر اس الثابتة. (B) زر اعة يدوي + حصـاد بالمحثـة الخلفيـة للجرار + در اس بآلة

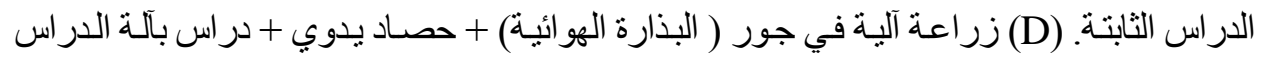

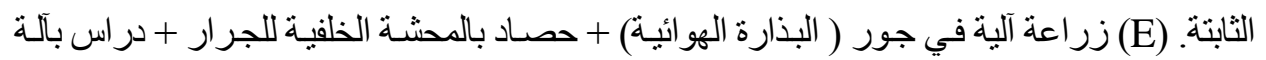

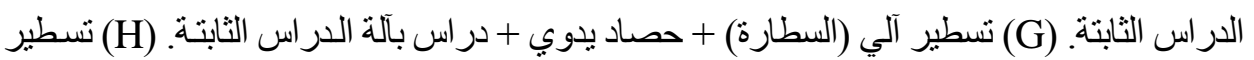

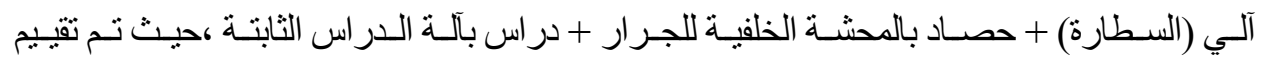
المعاملات من حيث تأثير طرق الزر اعة على بعض صفات النبات و إنتاجية المحصـول و ايضـاً تأثنير

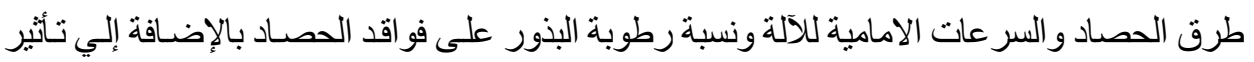
بعض العو امل على عملية الدر اس (نسبة الرطوبة للبذور - سر عة الدرفيل) مع الأخذ في الإعتبار كل من الطاقة المطلوبة لعمليات الميكنة المختلفة لمحصول الفاصولياو التكاليف المطلوبة لهذة العمليات.

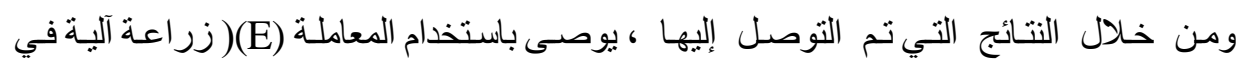

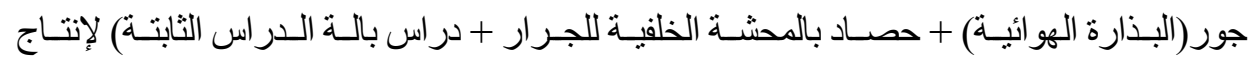

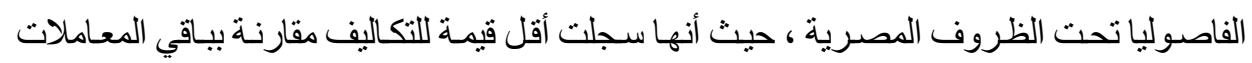

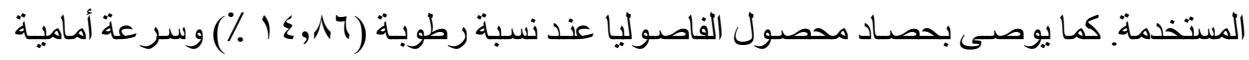

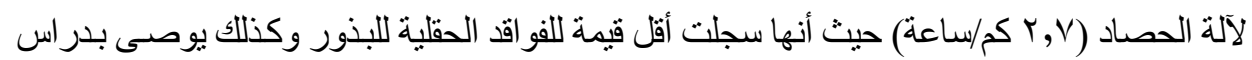

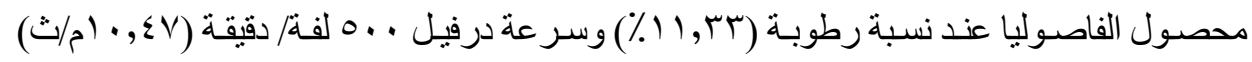
حيث أنها سجلت القيم المناسبة من القدرة وفو اقد البذورة ربه

' أستاذ الهندسة الزراعية المتفرغ - كلية الزراعة - جامعة جامعة الزقازيق- مصر.

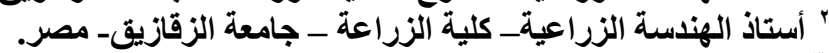

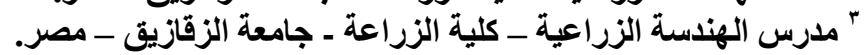

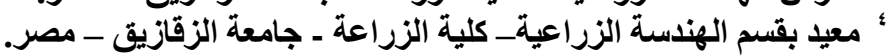

